Myriam Denov

Christine Gervais

\title{
Negotiating (In)Security: Agency, Resistance, and Resourcefulness among Girls Formerly Associated with Sierra Leone's Revolutionary United Front
}

When I started looking for girls in numerous war situations, I found silences and empty spaces, punctuated only by a handful of researchers focusing on children in general and girls in particular. Their stories account only for the smallest percentage of scholarly and popular work on social and political violence and systems of injustice. . . . Too often the girls are considered only as silent victims of (sexual) assault-devoid of agency, moral conscience, economic potential or political awareness. . . We need to ask girls to tell their own stories of war . . . rather than assuming the right to speak for them.

-Carolyn Nordstrom 1997, 5, 36

ar has traditionally been regarded as a masculine phenomenon and tends to be inherently linked to male aggression, violence, and brutality. In direct contrast, and perpetuating a misleading binary, depictions and representations of women and girls during war have tended to focus on their passivity as victims, peacemakers, wives, and mothers, or as appendages to males who are regarded as the true participants in war. Moreover, as the above quotation clearly illustrates, although men have been perceived as the primary agents in war, women have been rendered largely as silent and invisible victims. Although there is little question that girls and women endure profound violence during armed conflict, their roles within the context of armed conflict are increasingly

The first author would like to thank the Children's Rights and Protection Unit at the Canadian International Development Agency for its generous support of the study upon which this article is based. Deepest thanks, admiration, and gratitude go to the girls whose stories are highlighted in this article. The research team was consistently moved and humbled by their strength, candor, and insights. This article is dedicated to them.

[Signs: Journal of Women in Culture and Society 2007, vol. 32, no. 4]

(C) 2007 by The University of Chicago. All rights reserved. 0097-9740/2007/3204-0002\$10.00 
fluid and diverse. ${ }^{1}$ In fact, women and girls are involved, often simultaneously, in myriad aspects of armed conflict as perpetrators, actors, porters, commanders, domestic servants, spies, bodyguards, human shields, and sex slaves. Their roles are multidimensional and often contradictory and require that women and girls negotiate and renegotiate their security and well-being in a context that is anything but stable (Moser and Clark 2001). In the case of girls, the chronic quest for safety and security, regardless of the nature of their roles, may be even more challenging because of their vulnerability, which is exacerbated by their gender, age, and relative physical disadvantage (Fox 2004; Denov 2006).

Gender is a significant and unique dimension of security-related experiences and shapes the ways in which security is envisioned, ensured, and experienced (Caprioli 2004; Fox 2004). Moreover, the detrimental impact of sexism and patriarchy on experiences of insecurity reinforces the contention that security is not a gender-neutral concept (Crawley 2000). As Lene Hansen and Louise Olsson claim, "security is gendered through the political mobilization of masculine and feminine identities that are linked to practices of militarism and citizenship" (Hansen and Olsson 2004,406 ). Women's and particularly girls' experiences of violence and insecurity differ considerably from those of men and boys, especially because of their sexual and physical vulnerability (Cockburn 2001; Giles and Hyndman 2004; Denov 2006). Caroline Moser and Cathy McIlwaine (2001, 178) echo this contention and add that females and males have different perceptions of the violence that affects them. Gendered perceptions of violence are important considerations in analyses of females' quests for security because perceptions shape individuals' interpretations of and approaches to both dangers and solutions. Acknowledging gender as a noteworthy component of security not only allows for nonstate and more individualized conceptions of security, but such recognition of gendered and personalized dimensions of security may also foster more authentic articulations of security that shed light on relations, experiences, needs, dynamics, variances, and negotiations of security and insecurity (El-Bushra 2000; Macklin 2004).

Although the emerging literature on gender and conflict has begun to highlight the vast insecurities that girls may face in the context of war

\footnotetext{
${ }^{1}$ These forms of violence include rape, forced impregnation, mutilation, torture, displacement, enslavement, sexual exploitation, trafficking, and death (Meertens 2001; Turshen 2001; Handrahan 2004). The associated conditions of impoverishment, starvation, injury, and disease, as well as the loss of family, employment, residence, and nationality, are equally devastating (Fox 2004).
} 
(see McKay 1998; McKay and Mazurana 2004), given the frequent focus on the wartime victimization of girls, relatively few studies have attempted to articulate or understand the ways in which war-affected girls actively seek to ensure their own security within the highly insecure context of armed conflict, as well as their roles as active agents. ${ }^{2}$ A few exceptions to this have been the contributions of Carolyn Nordstrom (1997), Paul Richards (1998), Mats Utas (2003, 2005), and Alcinda Honwana (2006), who have all emphasized the importance of recognizing agency among war-affected children and, in particular, the realities of girls and women. To contribute to and expand upon this growing literature, this article explores the ways in which a sample of girls formerly associated with Sierra Leone's rebel Revolutionary United Front (RUF) experienced and subsequently attempted to avoid, minimize, or resist wartime abuses and insecurities.

We first provide a brief history of the conflict in Sierra Leone and, in particular, its effect on girls. After outlining the methodological approach to the study of girls formerly associated with the RUF, we explore girls' experiences of insecurity and victimization within the context of the decade-long civil war. We then trace the diverse ways in which this sample of girls actively negotiated their insecurity through the use of agency, resourcefulness, and modes of resistance. Finally, we highlight the implications of girls' responses to insecurity for larger debates concerning gender, war, and security.

\section{Sierra Leone's civil war and its effect on girls}

Like much of sub-Saharan Africa, Sierra Leone was integrated into the world system in a way that marginalized its traditional social systems and left its economy colonized by international enterprises and a kleptocratic governing elite. Over time, with poor governance and a weak economy, educational and occupational opportunities for young people were consistently undermined (Richards 1998). Moreover, within the context of widespread government corruption, mismanagement, and institutional collapse, and with more than half the population of Sierra Leone under the age of eighteen, disillusionment and anger among young people was

\footnotetext{
${ }^{2}$ The issue of agency and the search for security are clearly applicable to the wartime realities of both boys and girls. However, given their relative invisibility in scholarly literature, this article focuses on the circumstances of girls. For further discussions of agency with a sample of boy soldiers in Sierra Leone, see Maclure and Denov (2006) and Denov and Maclure (forthcoming b).
} 
infectious and volatile. Capitalizing upon the growing mass disillusionment, former Sierra Leonean Army corporal Foday Sankoh (who was backed by Liberian warlord Charles Taylor) formed the rebel Revolutionary United Front of Sierra Leone. Relying on the emancipatory rhetoric of "freedom, justice and democracy to all Sierra Leoneans" (Revolutionary United Front/Sierra Leone 1995), Sankoh systematically recruited largely uneducated, unemployed, and unemployable male youth who were linked to the informal underground economy to join a movement against the government (Abdullah 1998). In circumstances of mounting insurgence, traditional institutions were gradually replaced by militarized structures that were sustained by an ethos of extraordinary violence. When Sankoh's message of political revolution failed to attract popular support, the RUF's aim of broad social emancipation was sidelined by the goals of wealth, power, and control of the country's diamond mines. Marked as one of the most unrestrained fighting forces in recent history, the RUF invaded Sierra Leone from Liberia in 1991 and embarked on a decade-long campaign of terror characterized by indiscriminate violence and brutality against civilians.

Sierra Leone's decade-long conflict had a particularly ferocious effect on girls and women. Although girls and women have been historically relegated to positions of dependency within traditional systems of patriarchy, the political and economic decline and corresponding erosion of civic structures in the 1980s exacerbated female vulnerability. Following the outbreak of hostilities in the early 1990s, the already bleak situation of girls rapidly deteriorated into a nightmare of abuse and horror. Throughout much of the conflict, young females were systematically abducted by warring factions (mainly rebel forces) and forced to assume the roles of combatants, commanders, wives, or slave laborers-often a combination of these roles (Denov and Maclure 2006). In fact, nearly 30 percent of children associated with the RUF were girls (McKay and Mazurana 2004). Alongside the boys, girls became both victims of and participants in brutal forms of violence and terror. ${ }^{3}$ Before providing an account of the ways in which a sample of these girls negotiated their safety and security within the militarized context of life with the RUF, we describe our study's methodology.

\footnotetext{
${ }^{3}$ Undoubtedly, child soldiers are simultaneously perpetrators and victims of violence. Their plight is complex: as they actually perpetrate violence, child soldiers remain victims of coercion, terror, and deception.
} 


\section{Methodology}

Our examination draws on fieldwork conducted by Myriam Denov and Canadian and Sierra Leonean research partners in 2003 and 2004, which included in-depth qualitative interviews with forty girls formerly associated with the RUF living in the Eastern, Southern, and Northern Provinces and the Western Area of Sierra Leone. ${ }^{4}$ At the time of the research fieldwork, all the girl participants were between fourteen and twenty-one years old. The girl respondents had been under the age of eighteen years before the end of the conflict and had been under the control of the RUF for a period ranging from a few months to seven years. To be included in the study, participants were required to have been associated with an armed group in Sierra Leone (either voluntarily or through coercion) while under the age of eighteen. ${ }^{5}$ No stipulations were made regarding the length of time that girls were attached to an armed group or their assigned role within the group. A significant effort was made to gain a "thick description" (Geertz 1973) of the mental and experiential world of girls formerly associated with the RUF and the transitions into and out of violent conflict that have been inherent to this world.

The research team also consisted of six female adolescent researchers who had been part of the RUF fighting forces during the conflict. These six girls were involved in several aspects of the project, including the creation of research instruments, the recruitment of research participants, data collection, and dissemination of the research findings at a local community conference in Sierra Leone. ${ }^{6}$ Involving the girls in a purposeful activity proved to be educational and empowering for them. Moreover,

${ }^{4}$ This research was part of a larger study funded by the Canadian International Development Agency. The research was conducted by Myriam Denov (the project's principal investigator and this article's primary author), in conjunction with Richard Maclure of the University of Ottawa; Abdul Manaff Kemokai of Defence for Children International, Sierra Leone (DCI-SL); and a Sierra Leonean research team from Defence for Children International, Sierra Leone.

${ }^{5}$ In this study, the definition of a child coincides with the definition set out in the UN Convention on the Rights of the Child. According to the convention, a child is defined as "every human being below eighteen years" (article 1). For the text of the convention, see the United Nations Office of the High Commissioner for Human Rights, http://www .unhchr.ch/html/menu3/b/k2crc.htm.

${ }^{6}$ Denov conducted in-depth research training workshops with the adolescent researchers. Training focused on the goals of the research, on interview techniques with children, on gender and cultural aspects of interviewing, on ethical issues, and on the potential challenges they were likely to face in the field. As part of the training, young female researchers undertook mock interviewing and mock focus-group discussions as a way to hone their new skills. 
such an inclusive approach reinforced and grounded research on, by, and for girls.

A grounded theory approach to both data collection and analysis, which uses inductive forms of analysis to gain an understanding of the patterns that exist in the social world under study (Glaser and Strauss 1967), was essential to ensuring that the voices and perspectives of participants became the central component of the analysis and facilitated an authentic presentation of girls' experiences (Stasiulis 1993; Lyons 2004, 282). ${ }^{7}$ This grounded theory approach also coincides with a human security approach that seeks to move beyond conventional definitions of security, which tend to be state-oriented and as a result tend to exclude relevant human dimensions (Higate and Henry 2004). Our particular interest is to acknowledge and integrate individualized and experiential accounts of both security and insecurity, especially "from the bottom up" (Hoogensen and Rottem 2004, 161); incorporating these accounts through a human dimension into security studies identifies people, and not the state, as security studies' unit of analysis and as their priority of intervention (UN Development Programme 1994, 23).

The human security framework also acknowledges that while security is a political issue, it is also a very personal experience, often associated with fear and agony under threats of violence (Macklin 2004, 82). Such a contention is reinforced in Alexander Wendt's claim that "security is to a large extent what actors make of it" (Wendt 1992, 404). As such, the human security approach legitimizes individualized experiences of security and insecurity (Hansen and Olsson 2004). By placing the security of the person at the forefront of analysis and intervention, the approach extends beyond mere reflection of individual needs and actually enables security to be considered and determined at the individual level (Giles and Hyndman 2004, 12). As a result, security becomes definable both by and for individuals themselves and thereby becomes more authentically understood (Stasiulis 1993). This grounded and "trickle up" approach allows for more personalized and experiential accounts of security and insecurity to ultimately be voiced (Hoogensen and Rottem 2004, 163) and for those

\footnotetext{
${ }^{7}$ We share Tanya Lyons's $(2004,282)$ concerns about the inappropriateness of using marginalized females' voices to produce a Western academic text. However, we are also cognizant of the openness advocated by Daiva Stasiulis's (1993) antiessentialist position on authentic voice. In light of these considerations, we have attempted to create a space where the marginalized voices of the girls formerly associated with Sierra Leone's RUF can be communicated while being mindful of both dignity and diversity.
} 
most marginalized, particularly women and children, to be prioritized in security concerns (Fox 2004, 475).

The mutually enhancing relation between a grounded theory approach and a human security approach is a useful methodological and conceptual base for our emphasis on the narratives of girls formerly associated with Sierra Leone's RUF. As Gunhild Hoogensen and Svein Rottem (2004) and Mary-Jane Fox (2004) advocate, such a grounded and human-oriented approach opens up spaces for articulations of security, particularly by females. It is within this light that we explore the real-life insecurity experiences of girls from the RUF as they are articulated by the girls themselves.

\section{Life in the RUF: Girls' experiences of insecurity and victimization}

Given the war-torn situation in Sierra Leone and the insecurity of people throughout the country, girls inevitably reported feelings of insecurity and victimization prior to their abduction by the rebels. However, it was clear that their sense of insecurity was heightened - to the extreme-when they were coercively and violently separated from their families and communities and forced to join the rebels. All forty girls interviewed reported being abducted by the RUF under circumstances of extreme brutality and fear. In most cases, rebels invaded their villages and communities, and, under the threat of a gun, the girls were ordered to join the movement. As one girl explained: "During one of their numerous attacks, the rebels succeeded in driving the progovernment forces from our community. We hid ourselves in our house. The firing was so intense. Most people were running helter-skelter. After the fighting and firing subsided, rebels entered our house and forcefully picked me among my brothers and sisters. . . . Who would dare refuse? Not even if you were mad. . . . So they took me away. . . . I did not know what we were heading for and what they wanted to do with me. I was in total fear." ${ }^{8}$ Following their abduction,

\footnotetext{
${ }^{8}$ All interviews were conducted by Myriam Denov of McGill University, Abdul Manaff Kemokai of DCI-SL, and a number of talented research assistants from DCI-SL. Interviews were conducted in the participant's maternal language (either Krio, Mende, Temne, or Limba), translated into English by the Sierra Leonean research assistants at DCI-SL, and later transcribed. All interview transcripts are in the possession of Myriam Denov, and all quotations in this text emerge from data collected from these interviews. Given that participants were interviewed several times over the course of the two-year research project, often in different locations and regions of the country, information on the date and location of each interview has not been included. To ensure confidentiality and anonymity, all names of participants have been omitted from the text.
} 
and in the context of ongoing fear, girls were assigned an array of domestic and supportive tasks including cooking, washing, taking care of young children, and carrying heavy loads of ammunition, supplies, and arms. Failing to carry out their duties often meant enduring extreme forms of punishment, including brutal physical assaults, starvation, and even death: "If you refused or failed to do what you were told, they would put you in a guardroom or tie you up or one of the commanders might pass a command saying 'kill that person for not taking orders.' If you were obedient, you would be fine. But if you attempted escape and you were caught in the act, you would be killed without delay."

Girls quickly learned of the RUF's culture of violence and constant terror that surrounded them. The violence within the RUF appears to have been an integral feature of daily interaction and ranged along a continuum from verbal abuse to outrageous acts of cruelty. The girls suffered severe physical abuse at the hands of those who commanded them, particularly in the early stages of their recruitment. They were also witnesses to brutal forms of violence against men, women, and children who were both RUF combatants and civilians, acts that were clearly intended as public displays of horror. Violence and the threat of violence were used not only as a means to ensure total compliance and obedience but also as a form of indoctrination into and desensitization to the RUF's campaign of terror (Maclure and Denov 2006). Moreover, children were intimidated with terrifying warnings that any attempts to escape their captors would be met with death: "Some children tried to escape and they were caught. They shot some of them and the rest were thrown down a well and drowned. We witnessed this and decided that we should not try to escape."

While a constant aura of menace and terror seems to have been the basis of social structure, cohesion, and authority within the RUF, the patriarchal power structure and institutionalized gender differentiation also rendered almost all girls culturally and physically subservient to their male counterparts. The reality of repeated sexual violence, one of the key sources of insecurity for girls in the RUF, was the embodiment of such patriarchal power relations. Sexual violence, whether gang rape, individual rape, rape with objects, or all three, was a daily occurrence for most girls. ${ }^{9}$ In fact, all but two girls interviewed for this study reported being victims of repeated sexual assault by numerous male RUF fighters. These narratives reveal the brutality of these acts: "One afternoon, two rebels raped

9 Sexual violence was reportedly perpetrated predominately by boys and men. However, girls also reported a few instances of sexual abuse by adult female commanders. 
me. It was very painful. I cried right through the act. But even when I cried for mercy, they wouldn't listen to me. They tied my hands. . . . After the first man raped me, I was helpless. By the time the second guy was on top of me I didn't even know what was happening. When they had finished, I had blood between my legs and I couldn't walk because of the pain. . . . I felt very awful. I was ashamed of sitting among other people, I really felt like just dying." Similarly, this girl explained: "Rape was just normal with the group. . . . When I was newly captured, I was raped. . . . I was too small to be raped. . . . I cried and pleaded with the man to let go of me. He didn't. He went right on and did exactly as he wanted. . . . That night I cried and cried. . . . I was bleeding profusely. . . . For a whole week I sat and grieved."

In addition to repeated sexual violence, the majority of girls in the sample were forced to marry rebels, whereby a particular girl was deemed the sexual property of a specific RUF male. In Sierra Leone, this sexual slavery was euphemistically referred to as "bush marriage" or "AK-47 marriage": "I was twelve years old at the time. There was one man, a commander, who took me for his own. But other rebels demanded sex from me too. Whenever the commander was away, the other men would come after me and rape me. Some were in full view of others. Sometimes they would take me into the bush to rape me. They seemed to do it more often when they were taking drugs."

Another source of insecurity for girls was their forced involvement in highly dangerous combat activities and the use of small arms and light weapons. As with other countries that have experienced internal civil wars rather than cross-border conflict between countries, small arms were the weapons of choice for combatants in Sierra Leone. Cheap and efficient firearms, often purchased through illicit diamond sales, were widespread throughout the conflict. Following their abduction, girls reported being introduced to the foreign and dangerous world of small arms, and some were provided with rudimentary training. The transition into this world was not an easy one and brought about extreme fear, anxiety, and bitterness. As these girls explained: "I was not happy about it [having to use guns]. It was scary for me because I feared guns a lot." "I wasn't very good at [using weapons]. They took us to a base to learn how to use the weapons. I didn't learn very well. At one point my gun misfired and I was nearly killed. . . . I really had fear in my heart." This girl explained: "It was not the place for a little girl to hold a gun. I was so bitter. . . . I wanted an education, not to know how to fire a gun."

Although many girls were initially delegated supportive roles in the RUF, as the conflict wore on, for some girls, combat activities and the 
manipulation of small arms formed the crux of their involvement in the conflict: "Initially, my job was to carry heavy loads, but later I became part of the fighting force, to attack and defend. . . . We attacked convoys of vehicles, including military trucks, we killed people randomly and when we overcame them, we took all of their goods and set fire to their vehicles. . . . They normally told me that I was good at attacking when on the offensive, but I did not appreciate it and I was not convinced. I did it to save my life."

These experiences of combat brought forth extreme fear and insecurity. With little experience in handling weaponry, and with chaos and the madness of violence surrounding them, girls were afraid for their lives: "Each time we were preparing for combat, I was afraid for my life. The government soldiers and the Economic Community of West African States Monitoring Group who we were fighting had much more powerful machine guns than us. We were given drugs to overcome our worries and fright."

These testimonies have uncovered gripping perceptions of human and gendered insecurities. These insecurities were gendered through the transposition of patriarchal power structures onto a militarized terrain whereby traditional female roles were entrenched in the daily practices of the conflict. The gendered vulnerability and subservience of girls were manifested through the sexual violence, forced marriages, childbearing and child rearing, domestic chores, and supportive tasks that girls were subjected to during the militarized conflict. Such predominantly girl-specific tasks were performed and required in addition to their duties as fighters and spies.

For the girls formerly associated with the RUF, the terror and brutality of the war in Sierra Leone created a myriad of insecurities that were inevitably related to the limited entitlement that the girls had to even the most basic survival needs. The sexual, physical, personal, spatial, social, political, and health insecurities experienced by the girls occurred within extreme conditions of coercion, chaos, and deceit and consequently generated fear, humiliation, and bitterness. Although such constraining and vulnerable circumstances may seemingly limit girls' capacity to protect themselves, the girls nevertheless attempted to negotiate these challenges and gendered insecurities with resistance and resourcefulness.

Negotiating (in)security: Girls' agency, resourcefulness, and resistance Amid chaos and vulnerability, females have engaged in alternative mobilization efforts to ensure as much personal survival and communal security as possible (Cordero 2001). In the context of the violence expe- 
rienced by war-affected girls, ingenuity and creativity became strategic to individual survival and security. Despite their ongoing anxieties and brutal forms of victimization, the girls made conscious attempts to protect themselves and negotiate their security during their time with the RUF. Their attempts to negotiate their safety involved a variety of means, including using small arms, aligning themselves with a powerful male commander, perpetuating severe acts of violence, and engaging in subtle acts of acquiescence as well as bold acts of resistance. These mechanisms, which carried varying degrees of success, highlight the girls' capacity for negotiation and agency as well as resourcefulness, resistance, and mutual forms of support.

\section{Power and small arms}

When first coerced into the ranks of the RUF, the girls perceived the use of small arms as a source of insecurity and fear. However, as the conflict dragged on, and through ongoing observations and relations with their commanders and other child soldiers, the girls became increasingly aware that carrying a gun often increased their protection within the ranks of the RUF and in some cases decreased their chances of victimization. In light of this, the girls came to see small arms as a way to increase their safety and security and, reflecting both their agency and resourcefulness, over time became eager to possess their own weapon: "I was eager to become a soldier and have my own gun so that I would be able to resist threats and harassment from other soldiers." In a similar vein, this girl explained: "The gun became my bodyguard and protector. The gun was power, and that's why I was anxious to have one."

Moreover, in a context of continued victimization and powerlessness, ownership and use of a gun often brought the girls a sense of power, authority, and supremacy, particularly over civilians. As one participant described, "I felt powerful when I had a gun. As long as you are holding a gun, you have power over those who don't. It gave me more status and power." Another girl echoed this sentiment: "The gun made a big difference between us and the civilians. Naturally, you feel powerful when you have a gun in a war situation. One of the ways officers used to punish us was to take our guns from us. Some soldiers were not able to live without a gun."

Girls' feelings of power and confidence in relation to handling weaponry must be seen, however, within the context of gender dependency and subservience. Through the use of small arms, girls appear to have experienced a sense of release from previous relations of victimization and 
submission. More specifically, some girls were able to reframe and transform their original fear of small arms into instances of supremacy and power that afforded them, albeit minimally, a greater sense of security.

\section{Perpetrating acts of violence}

The RUF became notorious for its brutal atrocities committed against civilians and entire communities (Abdullah 1998). Being forced to live within this overarching culture of violence, as time went on, children, through a combination of indoctrination, terror, desensitization, and militaristic training, became active participants in conflict (Maclure and Denov 2006; Denov and Maclure forthcoming b). The more aggressive girls were seen to be, and the more destruction and looting they undertook, the more valuable they were within the ranks of the RUF. Girls became increasingly conscious of the fact that the more violent they were, the safer they became within the armed group. As one of the girls described: "I committed a lot of violence. . . . We were cherished by the senior officers for our wicked deeds." "I would tie people up, kill, and loot people's property. . . . I was not too good at shooting, but I was an expert in burning houses. We would enter the house after the enemy left the area and set fire to it using kerosene or petrol. I had to survive, and some of the ways to do it were to get involved in those violent acts."

Importantly, engaging in extreme forms of violence also brought privileges within the RUF, such as better access to food and looted goods, and in some cases led to promotion within the ranks. Promotion to the rank of commander was deemed to be the peak of success within the RUF: "Very violent and obedient soldiers were given positions as commanders. You needed to show enthusiasm, be very active during combat and terrorize and abduct civilians. . . . I was very active in combat and also captured a lot of people, including children. This contributed to my elevation to the status of a commander."

Although a minority of respondents reported being promoted to a commander, those who did recalled this event with nostalgia and even pride. The promotion elevated their status and allowed them to lead their own units of child combatants and contributed to their protection through their entourage of child bodyguards: "I was a commander not only for children but also for soldiers older than myself. Commanders were generally treated better regardless of their age or sex. I had six bodyguards. . . . They were very loyal and they did everything I ordered without questioning. . . . As commanders we needed bodyguards to boost our morale and to show other people our status. [This was important] because we didn't have badges, uniforms, or crowns to depict our status. . . . I 
was given a lot more status and protection as a commander." It is entirely possible that some girls came to embrace the power of being a perpetrator and the rewards stemming from their violent actions. However, given that extreme acts of violence appeared to ensure girls' survival, reduce their own victimization, and even assure them higher status in the ranks of the RUF, acts of perpetration can be regarded as strategic attempts at negotiation.

\section{Marriage to a powerful commander}

Marriage and sexual relations are often referred to as necessary exchanges for the survival and protection of both female combatants and female captives (Dinan 2002). In what have been called sex-for-soap exchanges, some females negotiate their hygienic and food needs "by using their positions as women (being [sexually] available to men)" (Lyons 2004, 191). Others seek protection from physical and sexual abuse through sex or marriage (Ibañez 2001). Depending on the severity of the power dynamics, marriage and sexual relations may be perceived as either active or passive on the part of the girls; in either case, some level of agency or attempt at negotiation is evident.

As noted earlier, the reality of sexual violence was a devastating feature of everyday life for girls in the RUF. Within a powerful patriarchal structure, the girls in this study became mere property of male RUF members, with their bodies being used as resources to be exploited and even as gifts and rewards (Maclure and Denov 2006). Girls were thus constantly aware of the potential threat and danger of sexual violence by their adult commanders as well as by other men within the armed group. Within this context of profound insecurity, girls realized the importance of actively aligning themselves with a high-ranking male commander through a bush marriage. As Utas has argued within the context of war-torn Liberia, "intelligent and smart young women were seen parading with the most powerful commanders" (Utas 2005, 75). Although these marriages to individual male commanders were often highly repressive, violent, and abusive, they were preferable to the alternative of being ongoing victims of gang and individual rape by countless members of the fighting forces. ${ }^{10}$ As one girl explained, "When one of the commanders proposed love to you, sometimes you had to accept even if you really were not willing to cooperate. This was preferable to being gang-raped."

${ }^{10}$ Here we acknowledge the relativity of security under such repressive circumstances. While marriage may have rendered a girl more secure, the context in which she benefited from a certain level of protection was still very insecure. 
As the following narratives illustrate, marriage to a powerful commander not only protected the girls from daily sexual violence and physical abuse by other males in their group but also elevated their overall status within the RUF: "The girls who were serving as wives were treated better, and according to the rank and status of their husbands. . . . At the beginning, I was raped daily. . . . But later an officer had a special interest in me. He then protected me against others and never allowed others to use me. He continued to have sex with me alone and less frequently. . . He gave me protection from the other men." Similarly, this participant explained, "Girls who were wives of senior officers were treated according to the status of their husbands, so it was good for any girl to have a senior officer as a lover. They had more power and status."

Given the increased security associated with marriage, perhaps not surprisingly girls reported actively trying to gain the sexual attention of powerful males in the RUF. As one girl stated, "I was married in the bush . . . it was more advisable to have a husband than to be single. Women and girls were seeking [the sexual attention of] men-especially strong ones for protection from sexual harassment."

Reflecting agency and resourcefulness, girls' marriage to a powerful commander can thus be seen as a clever strategy to actively find protection, power, status, and survival. Moreover, such strategic instances, albeit in highly insecure conditions, serve as significant examples of girls' abilities to negotiate and in some cases thwart or limit their own potential victimization through the use of conventional gender roles. Although bush marriages may be perceived as a form of sexual slavery, they have also served as a site at which some girls reframe their victimization and, however minimally, transform it into a more secure space. The complexity of bush marriages illustrates how patriarchal norms and gender expectations can sometimes create both insecurity and (relative) security for girls in times of war (Handrahan 2004).

\section{Modes of acquiescence and resistance}

Acquiescence to the RUF's doctrines was a resourceful way for girls to ensure their safety. Moreover, acceding to forms of victimization enabled them to stave off more extreme forms of cruelty. As Kinsey Alden Dinan (2002, 1127) and Miranda Alison $(2004,462)$ have observed elsewhere, girls strategically exploit gendered obedience and gendered divisions of labor to their advantage. For example, some female combatants were intentionally subservient in and deliberately excelled at domestic chores, such as cooking and cleaning, so that they could be relegated to mundane camp tasks and thus avoid being sent into the bush to shoot and kill. In 
the following narrative, one girl explained her resourceful tactic to avoid warfare: "I was responsible for cooking, and I always did it well because I did not want to leave the [domestic duties] for jobs like combat that were more deadly." Interestingly, this girl's testimony once again demonstrates how other young females use conventional gender roles (e.g., patriarchy-based domestic duties) to their security advantage (Alison 2004).

Strategies of resistance alongside acquiescence by women in conflict situations have been documented across several continents (Jacobs 2000; Preston and Wong 2004). Examples of such resistance include the refusal to act, refusal to assent to violence, silence, escape, and termination of pregnancy in the cases of rape and ethnic cleansing tactics (Jacobs, Jacobson, and Marchbank 2000; Keitetsi 2004). The risks associated with resistance are often grave and even fatal and are thus a testament to the degree of courage exhibited by these women and girls (Denov and Maclure forthcoming a).

For the girls interviewed for this research, there was little room for defiance or opposition in the RUF environment where obedience to authority and conformity to the values of the RUF were imperative to children's very survival. Nonetheless, despite the potential consequences of injury and even death for noncompliance, many girls engaged in acts of resistance. Forms of resistance varied and included developing strong relationships with other girls and women. By creating a sense of female solidarity and by inherently excluding the males, girls within the RUF were able to attain a degree of solace and comfort and could subtly resist patriarchal authority structures. Although some would argue that the creation of strong female relationships can be considered a common survival strategy used by war-affected females historically, one must consider the unique context in which the girls in this study were living. Within the RUF, any form of socializing or sharing of their current thoughts, feelings, or information about their former civilian lives was strictly forbidden and highly punishable, even by death. As one girl explained: "If we came from the same place and we knew each other, we would share a few jokes or sit together and share thoughts and memories of home. This would go on until perhaps one of commanders came and said, 'What are you sitting here for? What are you doing?' We would then pretend we were doing something else so that they would not learn of what we were actually engaged in. Because at those times, if you were caught in acts like that, you [could be killed]."

Given the dangerous and volatile context and the repercussions of being discovered for socializing, engaging in personal discussions and building 
a sense of solidarity can be considered more passive forms of resistance. Such communicative structures among girls, whether formal or informal, open or secret, were instrumental to their psychological and emotional well-being during armed conflict. As an example, one girl reflected upon the importance of talking to and sharing with other girls about her experience of rape: "One day a girl was brutally raped and she bled so badly she died. . . . I had heard about it and was so affected by it, but I was afraid to discuss it. . . . Two girls began discussing it, and I overheard them. We all sat down and started sharing our stories [of rape]. . . . I felt much better after this because I thought that I was the only one to have this happen to."

Other girls engaged in more active forms of resistance to ensure their survival. For example, girls reported using violent forms of resistance to retaliate against male perpetrators of sexual assault:

I stabbed one guy to death-he was always harassing me for sex. On that day he wanted to rape me and I told him that if he tried, I would stab him. He underestimated me and he never knew I had a dagger. He met me alone in the bush on my way to town after using the bush toilet. I knew that he and others were observing my movements . . . and I took the dagger along [to protect me from] rapists. As he attempted to rape me, I stabbed him twice . . . I was tired of the sexual harassment. He later died [from the stabbing].

Girls also recounted collective efforts at resistance by attempting to escape the RUF, all the while being fully aware of the consequences of violence or death if they were discovered: "It was impossible to escape because they had tight security and those who attempted and were caught were killed. . . . But at times [the children in our group] came together quietly to discuss ways of escaping from our captors. . . . Part of our job was to fetch water for the rebels. . . On one particular occasion no guards came with us. My sister told me to drop our buckets, and we ran into the bush. We stayed there for nearly a week, living only on fruits and raw cassava until we finally found our way to our own village." Another girl explained the circumstances surrounding her attempted escape: "I became very tired of always carrying the loads. Myself and a group of about five others decided that we would attempt an escape. We decided to use the opportunity of fetching water to do this. But one girl was not involved in the plan and she overheard us talking about it. She informed the commander about our plan . . . we were [punished] and confined to a small space and starved for several days." 
In the above case, when the respondent was asked why she thought her colleague had revealed the group's plan of escape to the commander, she replied, "I think that [the girl who revealed our plan to the commander] had a vested interest in having us all stay with her. If we escaped, she would have no friends or companions and she would be left to do all the chores and work by herself." By deceiving her fellow captives by reporting the plan of escape to the commander, the girl in question is herself actively using a survival strategy and a form of resistance. This demonstrates that while the young women acted in solidarity in some moments, in others they were in conflict and competition in their strategies of survival and resistance. Although most respondents were unsuccessful in their attempts to escape, it was clear that girls demonstrated a capacity to organize and to act both individually and collectively with extraordinary courage.

It is important to note that while there may have been a range of opportunities and choices available to girls in the process of exercising agency, in the context of wartime violence, agency often took on a rather defensive form. That is, for victims of incessant violence, especially sexual abuse, and within the context of oppressive hierarchical structures, the agency afforded to girls in conflict zones was often severely constrained (Alison 2004). Where and when agency was exhibited by the girls in this study, it was often under duress involving threats of torture, rape, and death. Under such repressive conditions, it took a significant amount of awareness, skill, vigilance, courage, and strength to avoid risk and to remain as secure as possible (Hoogensen and Rottem 2004). In this sense, the fluidity of the girls' roles is evident in that they were simultaneously victims and aggressors, as well as captives and combatants, often drifting between these categories (Denov and Maclure forthcoming a).

What the girls all had in common was that following their coercive introduction to the war system, they eventually began to understand the intricacies and internal workings of the system and subsequently created different ways to master it. The ways that these girls attempted to subvert the RUF were invariably shaped by the unique individual (psychological, personality, maturity, physical and mental strength, health), and contextual (structural, spatial, relational, geographic) opportunities and circumstances of each girl. Nonetheless, several factors appeared salient to the negotiation process, including age and length of time with the rebels.

Girls fifteen years of age and older who had more life experience and maturity appeared to be able to evaluate, appraise, calculate, and ultimately negotiate their situations with seemingly greater ease and confidence. There were, however, clear exceptions, as the study revealed several in- 
stances of very young girls - as young as age nine-who actively planned and executed a successful escape from the RUF. On the whole, it would appear that younger girls who had less life experience and a limited understanding of the war dynamics and who were suddenly catapulted from the safety of their families and communities relied more heavily on modes of calculated acquiescence rather than bold resistance.

It would also appear that girls who lived among the RUF for longer periods of time and had time to observe, learn, and understand the system were more skilled at creating effective means of ensuring their security. For example, it took time and experience to discover that carrying arms, which was initially experienced as frightening and embittering, could actually be protective.

A final factor that appeared to propel girls to develop strategies of resistance was a result of the continued and unrelenting victimization. Girls who lived among the rebels for long periods of time and grew tired and weary from massive sexual, physical, and psychological insecurity developed bold strategies of resistance for their very survival. For example, the young woman who reported killing the man who attempted to rape her explained that she had grown "tired of the sexual harassment."

While there were marked similarities in the responses of girls associated with the RUF, their agency and ability to negotiate their security was invariably shaped largely according to the varying levels of experience, skill, maturity, courage, and opportunity of each girl. Such individual capacities and contextual circumstances were both formed and constrained by the dynamics of the conflict zone.

\section{The implications of girls' negotiations for wartime security}

The gendered abuses perpetrated within the RUF were extreme. The girls' efforts to negotiate their own security were thus born out of desperate and vital necessity. The girls made complex and compelling choices in the face of grave danger, inevitable harm, and unimaginable cruelty. The girls' own oral accounts provide several insights into aspects of females' relations to security, violence, agency, and war. In particular, the girls' narratives have uncovered the fact that, despite the horrors of armed conflict, some females find creative ways to bring about change by themselves and for themselves. The hardships endured in their quest for security shed light on the girls' strengths and struggles with negotiation, agency, resistance, resilience, resourcefulness, risk, courage, and support-concepts that were determined inductively through patterns that emerged from the data. Such 
concepts shed light on the complexities that shape and reshape girls' quests for survival and safety in the face of dire conditions.

In the narratives presented above, the emphasis on negotiation highlights how girls formerly associated with the RUF overcame obstacles and ordeals through various compromises and strategies. For females associated with armed groups, the insecurities and obstacles are extremely difficult to overcome and often require very cautious maneuvering. In the case of RUF girls, negotiation involved both passive acquiescence and active attempts to manipulate situations.

In addition, the attention drawn to the various ways in which girls envisioned and exhibited agency shed light on the deliberate actions, whether as victims or as perpetrators, that the girls took to accomplish particular goals, including survival, safety, and security. The girls' narratives reveal the ways that they actively engage in efforts to minimize their victimization and avoid combat or use combat as a protective measure. Of particular interest here is the courageous capacity of some girls to defend and protect themselves in the most vulnerable of circumstances, often amid state breakdown and in the absence of legitimate and formal support (Fox 2004). Such findings have reflected Judy El-Bushra's (2000) contention that opportunities and choices are often gendered and thus contingent upon and reflective of females' autonomy and capacity to think and act in the face of often oppressive hierarchical structures. It is important to note, however, that these acts of agency and resistance can be perceived as small victories in light of the circumstances of ongoing victimization and terror within the RUF.

In accentuating resourcefulness, examples of the girls' use of clever and competent problem-solving abilities in surmounting difficult situations have been underscored. In the context of the violence experienced by the war-affected girls in Sierra Leone, ingenuity and creativity became vital to individual survival and security. The use of intelligence techniques and physical force as well as the planning of defensive attacks to thwart violence are examples of the seemingly imperative resourcefulness of females during armed conflict. The creative ways that the girls coped with the chaos associated with the RUF certainly "call into question the stereotypical portrayal of women as mere victims of conflict" (Sharoni 2001, 87). Furthermore, in emphasizing resistance, the girls' narratives reveal the ways in which they opposed and struggled against their abusive captors and in so doing demonstrated their ability to counter, albeit on a limited scale, the damaging effects of extremely oppressive structures of violence and armed conflict. 
It is important to recognize that the girls' abilities to negotiate security during armed conflict can in no way be constituted as full female emancipation. As noted elsewhere in this article, the oppressive conditions of the conflict and the preexisting inferior social status of women and girls in Sierra Leone certainly shaped the degree of agency and resistance that the girls exhibited and the extent of security that they experienced. Nevertheless, as Valerie Preston and Madeleine Wong (2004, 169) have noted, whether as potential perpetrators or victims, it is possible for females to create new spaces of gender equality through resistance. Susie Jacobs extends this claim by reinforcing the point that an individual instance of resistance "may not amount to mass insurrection but nevertheless signals change in gender relations in directions which may enhance women's gender status" (Jacobs 2000, 232) and by extension their security. The narratives highlighted in this article certainly reinforce this potential. This potential, however, remains fragile given that girls and women are often irreparably scarred and marginalized by the traumatic effects of war, conflict, and displacement.

As the narratives in this study have shown, instances of negotiation, agency, resistance, and resourcefulness do not necessarily occur in isolation. Rather, they tend to be manifested simultaneously and often in mutually reinforcing ways. Although they do not represent the totality of concepts available for the analysis of women and war, they do constitute a point of departure into which other females' experiences of war and other concepts may be integrated, debated, refined, and expanded.

Both the narratives and the conceptual analyses of this article have been framed through a human security lens that emphasizes individual experiences of security and prioritizes the personal security concerns of women and children. Nevertheless, it is imperative to situate these individualized narratives of both perpetration and victimization within broader structural contexts of patriarchal relations, national violence, global economies, and state and extrastate powers (locally, nationally, and internationally). The microlevel experiences of girls in Sierra Leone's RUF and their capacity to engage in negotiation and to act resourcefully and with resistance were undeniably shaped by broader parameters at gendered, political, economic, institutional, state, and extrastate levels. The constraints that exacerbated the vulnerability of young females include, more specifically, preexisting gender inequalities within Sierra Leonean society, the apparent impotency of the Sierra Leonean government in the face of an unrestrained RUF, the international diamond trade, the internal dynamics and institutional controls of the RUF, and weakened national economies and corrupt political governance. 
Despite these broader structural forces, our emphasis on the individual voices and experiences of girls remains a component of a more comprehensive analysis of gender, conflict, and security. Indeed, a combined micro- and macroanalysis that sheds greater light on the precursors, experiences, and consequences of females' lack of security within the conflict zones of the past may enable more effective preventative measures and appropriate protective solutions for girls in the future. ${ }^{11}$

\section{Conclusion}

In this article, we have sought to enrich current analyses and debates on females' experiences in armed conflict with a particular emphasis on human security. We aimed to project the voices of the girls so that they could relate their own stories. In so doing, we have demonstrated that the girls' accounts should be considered central and indispensable to understandings of female experiences of violence and not as alternative narratives in studies on lack of security during war. As the data reveal, within contexts of profound insecurity, girls were successful negotiators, decision makers, risk assessors, actors, and strategizers in the history of armed conflict in Sierra Leone. In this light, girls associated with the RUF in Sierra Leone challenge the dominant assumptions of females as merely marginalized and vulnerable populations during armed conflicts. This case therefore enlightens our understandings of the various adaptations to lack of security and reclamations of security and survival in which girls may engage simultaneously during war.

The ways in which girls make choices that manifest their agency under extremely adverse conditions have significant implications for long-standing debates within feminist scholarship on structure and agency, as well as within other scholarships on gender, security, and human rights. This study may thus contribute to comparative understandings of females' use of agency in their pursuit of security and rights within other oppressive structures, including domestic settings, repressive state regimes, educa-

${ }^{11}$ Both preventative measures and protective solutions should include, among others, gender mainstreaming in peace-building initiatives and conflict-sensitive development (ElBushra, Adrian-Paul, and Olson 2005, 29), gender sensitivity training among civilian and state officials, greater control over exploitative paramilitary groups, zero-tolerance policies on violence against females and children, fair-trade economies, greater political stability and accountability, and greater access to education and political power for females. Despite their ideal potential, these measures cannot be viewed as a panacea given that their implementation is most often hindered by contradictory policies and practices, lack of political and social will, and lack of funding. 
tion, and employment spheres, as well as in other conflict zones. Since this research offers only an initial examination of the conditions of young females' security and insecurity, further research on the interstices between and among conflict, security, and gender is warranted. Moreover, although the findings of this study have shed light on the diverse ways in which girls negotiated their security during the armed conflict, girls' perceptions of their actions during the conflict, as well as an examination of the longterm consequences of the strategies they adopted, were beyond the scope of the current research. Future research would benefit from exploring girls' impressions of their actions over time.

This article's emphasis on the capacity of girls to pursue their own security also has implications at the policy level. With their experiences of agency, negotiation, resistance, and resourcefulness, many girls formerly associated with Sierra Leone's RUF are undoubtedly equipped with incredible potential to contribute to projects of reconstruction, peace, development, justice, and security in the future. ${ }^{12}$ Political, social, health, educational, and legal spaces must therefore be granted to allow them to do so. As Hoogensen and Rottem $(2004,165)$ insist, the resources needed to ensure females' security will only be properly engaged when girls' and women's own articulations of security are acknowledged and heeded by state and nongovernmental authorities who are entrusted with the responsibility of providing protection, security, and healing for war-affected citizens. Such a human- and gender-oriented approach to young women's security needs must be integrated into local, national, and international programs that involve not only disarmament, demobilization, and reintegration processes in the postconflict phase but also and especially processes that encourage gender equality, peace building, and social, political, and economic stability in the preventative stages so as to inhibit potential conflicts and their devastating consequences, especially for girls and women.

Girls' efficacy in postconflict reconstruction initiatives must be carefully facilitated to meet the unique security needs of war-affected girls. Since females' subordinate status and prewar gender roles are often reinforced during postconflict periods, girls often face ostracism, betrayal, repression,

\footnotetext{
${ }^{12}$ Future studies should explore how young and adult women's experiences of insecurity in war affect the interplay of development, peace, justice, and security, on both personal and political levels, not only in the postconflict and reconstruction phases but also in the preventative stages. The interplay of development, peace, justice, and security is identified here as an essential condition to the postconflict reconstruction phases; the simultaneous and mutual reinforcement of these elements are crucial to success in this regard.
} 
and increased poverty, as well as exclusion from reconstruction programs (Cockburn 2001, 26). Under such considerations, their social, health, educational, political, and economic needs and rights must first be addressed. Girls must also be provided with safe and frequent opportunities for inclusion and equal participation in disarmament, demobilization, and reintegration programs and rights-based approaches so that their compelling voices and girl-specific experiences of agency, resilience, and innovation can be appropriately integrated into reconstruction policies and programs. Their participation must be voluntary and guided by supportive counseling; the forums for participation must also be genuinely receptive to the girls' testimonies. Such inclusive opportunities are imperative to maximizing the worthy and essential contributions of war-affected girls to their own postconflict societies. Clearly, their input conveys females' security needs and an informed gender perspective. It is valuable not only to efforts that work toward the long-term security of war-affected girls but also to local, national, and international policies and programs that strive preventatively for peace and security for all.

School of Social Work

McGill University (Denov)

Department of Criminology

University of Ottawa (Gervais)

\section{References}

Abdullah, Ibrahim. 1998. "Bush Path to Destruction: The Origin and Character of the Revolutionary United Front/Sierra Leone." Journal of Modern African Studies 36(2):203-35.

Alison, Miranda. 2004. "Women as Agents of Political Violence: Gendering Security.” Security Dialogue 35(4):447-63.

Caprioli, Mary. 2004. "Democracy and Human Rights versus Women's Security: A Contradiction.” Security Dialogue 35(4):411-28.

Cockburn, Cynthia. 2001. "The Gendered Dynamics of Armed Conflict and Political Violence." In Moser and Clark 2001, 13-29.

Cordero, Isabel Coral. 2001. "Social Organizations: From Victims to Actors in Peace Building." In Moser and Clark 2001, 151-63.

Crawley, Heaven. 2000. "Engendering the State in Refugee Women's Claims for Asylum.” In Jacobs, Jacobson, and Marchbank 2000, 87-104.

Denov, Myriam. 2006. "Wartime Sexual Violence: Assessing a Human Security Response to War-Affected Girls in Sierra Leone." Security Dialogue 37(3): 319-42.

Denov, Myriam, and Richard Maclure. 2006. "Engaging the Voices of Girls in the 
Aftermath of Sierra Leone's Conflict: Experiences and Perspectives in the Culture of Violence." Anthropologica 48(1):73-85.

—. Forthcoming a. "Girls and Small Arms in Sierra Leone: Victimization, Participation and Resistance." In Gender Perspectives on Small Arms and Light Weapons, ed. Vanessa Farr and Albrecht Schnabel. Tokyo: United Nations University Press.

- Forthcoming b. "Turnings and Epiphanies: Militarization, Life Histories and the Making and Unmaking of Two Child Soldiers in Sierra Leone." Journal of Youth Studies.

Dinan, Kinsey Alden. 2002. "Migrant Thai Women Subjected to Slavery-Like Abuses in Japan." Violence against Women 8(9):1113-39.

El-Bushra, Judy. 2000. "Transforming Conflict: Some Thoughts on a Gendered Understanding of Conflict Processes." In Jacobs, Jacobson, and Marchbank 2000, 66-86.

El-Bushra, Judy, with Ancil Adrian-Paul and Maria Olson. 2005. Women Building Peace: Sharing Know-How, Assessing Impact, Planning for Miracles. London: International Alert.

Fox, Mary-Jane. 2004. "Girl Soldiers: Human Security and Gendered Insecurity." Security Dialogue 35(4):465-79.

Geertz, Clifford. 1973. "Thick Description: Towards an Interpretive Theory of Culture." In his The Interpretation of Cultures, 1-16. New York: Basic.

Giles, Wenona, and Jennifer Hyndman, eds. 2004. Sites of Violence: Gender and Conflict Zones. Berkeley: University of California Press.

Glaser, Barney, and Anselm Strauss. 1967. The Discovery of Grounded Theory. Chicago: Aldine.

Handrahan, Lori. 2004. "Conflict, Gender, Ethnicity and Post-conflict Reconstruction." Security Dialogue 35(4):429-45.

Hansen, Lene, and Louise Olsson. 2004. “Guest Editors' Introduction.” Security Dialogue 35(4):405-9.

Higate, Paul, and Marsha Henry. 2004. "Engendering (In)security in Peace Support Operations." Security Dialogue 35(4):481-98.

Honwana, Alcinda. 2006. Child Soldiers in Africa. Philadelphia: University of Pennsylvania Press.

Hoogensen, Gunhild, and Svein Rottem. 2004. "Gender Identity and the Subject of Security." Security Dialogue 35(2):155-71.

Ibañez, Ana Cristina. 2001. "El Salvador: War and Untold Stories-Women Guerrillas." In Moser and Clark 2001, 117-30.

Jacobs, Susie. 2000. "Globalisation, States and Women's Agency: Possibilities and Pitfalls.” In Jacobs, Jacobson, and Marchbank 2000, 217-37.

Jacobs, Susie, Ruth Jacobson, and Jennifer Marchbank. 2000. States of Conflict: Gender, Violence and Resistance. London: Zed.

Keitetsi, China. 2004. La petite fille à la Kalachnikov: Ma vie d'enfant soldat [The little Kalashnikov girl: My life as a child soldier]. Brussels: Éditions GRIP. 
Lyons, Tanya. 2004. Guns and Guerilla Girls: Women in the Zimbabwean Liberation Struggle. Asmara, Eritrea: Africa World Press.

Macklin, Audrey. 2004. "Like Oil and Water, with a Match: Militarized Commerce, Armed Conflict, and Human Security in Sudan." In Giles and Hyndman 2004, 75-107.

Maclure, Richard, and Myriam Denov. 2006. “'I Didn’t Want to Die So I Joined Them': Structuration and the Process of Becoming Boy Soldiers in Sierra Leone." Journal of Terrorism and Political Violence 18(1):119-35.

McKay, Susan. 1998. "The Effects of Armed Conflict on Girls and Women." Peace and Conflict 4(4):381-92.

McKay, Susan, and Dyan Mazurana. 2004. "Where Are the Girls?" In their Where Are the Girls? Girls in Fighting Forces in Northern Uganda, Sierra Leone and Mozambique: Their Lives During and After War, 17-20. Montreal: Rights and Democracy.

Meertens, Donny. 2001. “The Nostalgic Future: Terror, Displacement and Gender in Colombia." In Moser and Clark 2001, 133-48.

Moser, Caroline O. N., and Fiona Clark, eds. 2001. Victims, Perpetrators or Actors? Gender, Armed Conflict and Political Violence. London: Zed.

Moser, Caroline O. N., and Cathy McIlwaine. 2001. "Gender and Social Capital in Contexts of Political Violence: Community Perceptions from Colombia and Guatemala.” In Moser and Clark 2001, 178-200.

Nordstrom, Carolyn. 1997. Girls and Warzones: Troubling Questions. Uppsala, Sweden: Life and Peace Institute.

Preston, Valerie, and Madeleine Wong. 2004. "Geographies of Violence: Women and Conflict in Ghana." In Giles and Hyndman 2004, 152-69.

Revolutionary United Front/Sierra Leone. 1995. Footpaths to Democracy: Toward a New Sierra Leone. n.p.: Revolutionary United Front of Sierra Leone.

Richards, Paul. 1998. Fighting for the Rainforest: War, Youth and Resources in Sierra Leone. Oxford: James Currey.

Sharoni, Simona. 2001. "Rethinking Women's Struggles in Israel-Palestine and in the North of Ireland." In Moser and Clark 2001, 85-98.

Stasiulis, Daiva. 1993. “'Authentic Voice': Anti-racist Politics in Canadian Feminist Publishing and Literary Production." In Feminism and the Politics of Difference, ed. Sneja Gnew and Anna Yeatman, 35-60. Sydney: Allen \& Unwin.

Turshen, Meredeth. 2001. "The Political Economy of Rape: An Analysis of Systematic Rape and Sexual Abuse of Women during Armed Conflict in Africa." In Moser and Clark 2001, 55-68.

UN Development Programme. 1994. Human Development Report 1994. New York: Oxford University Press.

Utas, Mats. 2003. "Sweet Battlefields: Youth and the Liberian Civil War." PhD dissertation, Uppsala University.

—. 2005. "Agency of Victims: Young Women in the Liberian Civil War." In 
910 I Denov and Gervais

Makers and Breakers: Children and Youth in Postcolonial Africa, ed. Alcinda Honwana and Filip de Boeck, 53-80. Trenton, NJ: Africa World Press.

Wendt, Alexander. 1992. "Anarchy Is What States Make of It: The Social Construction of Power Politics.” International Organization 46(2):391-425. 